International Research Journal of Management, IT \& Social Sciences
Available online at https://sloap.org/journals/index.php/irjmis/
Vol. 8 No. 6, November 2021, pages: 669-678
ISSN: 2395-7492
https://doi.org/10.21744/irjmis.v8n6.1975

\title{
The Relevance of Speaking Skills with Improving Digital Literacy
} Skills

\begin{tabular}{|c|c|}
\hline & $\begin{array}{r}\text { Mas'ud Muhammadiah } \\
\text { Petrus Jacob Pattiasina } \\
\text { Khasanah } \\
\text { Ali Pirdaus }\end{array}$ \\
\hline Article history: & Abstract \\
\hline $\begin{array}{l}\text { Submitted: } 27 \text { September } 2021 \\
\text { Revised: } 18 \text { October } 2021 \\
\text { Accepted: } 09 \text { November } 2021\end{array}$ & \multirow{3}{*}{$\begin{array}{l}\text { The author believes that learning English, especially speaking skills, is closely } \\
\text { related to the mastery of digital literacy skills among students at schools and } \\
\text { universities. To prove the assumptions and beliefs of the authors of this study, } \\
\text { take a look at some of the data that has been published in various journals, } \\
\text { books, and proceedings, as well as other internet data sources. Furthermore, to } \\
\text { make it easier for us to answer the questions in this review, we have carried } \\
\text { out a series of data analyses and studies by incorporating a coding system and } \\
\text { in-depth evaluation and interpretation so that we can derive findings in } \\
\text { response to these questions. Study the questions on the basis that, they are valid } \\
\text { and reliable. For example, we visited Taylor and Francis Elsevier publications, } \\
\text { Google book publications, academic databases, and domestic publication } \\
\text { journals. After a series of criticisms of the data and discussion of the findings, } \\
\text { we can finally say that there is strong evidence that there is a relevance between } \\
\text { successful mastery of speaking skills and digital literacy skills among students. } \\
\text { So with these results, we hope that these findings can be input in studies of the } \\
\text { success of learning English. } \\
\text { International research journal of management, IT and social sciences } \odot \text { } 2021 \text {. } \\
\text { This is an open access article under the CC BY-NC-ND license } \\
\text { (https://creativecommons.org/licenses/by-nc-nd/4.0/). }\end{array}$} \\
\hline $\begin{array}{l}\text { Keywords: } \\
\text { learning English; } \\
\text { literacy digital; } \\
\text { relevancy; } \\
\text { speaking skill; } \\
\text { study findings; }\end{array}$ & \\
\hline & \\
\hline \multicolumn{2}{|c|}{$\begin{array}{l}\text { Corresponding author: } \\
\text { Mas'ud Muhammadiah, } \\
\text { Universitas Bosowa, Makassar, Indonesia. } \\
\text { Email address: masud.muhammadiah@universitasbosowa.ac.id }\end{array}$} \\
\hline
\end{tabular}

a Universitas Bosowa, Makassar, Indonesia

${ }^{\mathrm{b}}$ Universitas Pattimura, Ambon, Indonesia

Universitas Siber Asia, Jakarta, Indonesia

d UIN Sulthan Thaha Saifuddin Jambi, Indonesia 


\section{Introduction}

Along with advances in information and communication technology, foreign language teaching had also made progress compared to foreign language teaching systems and methods in the period before the latest technology emerged (Nomass, 2013; Putra et al., 2020). The emergence of technology in education and teaching requires teachers and lecturers and foreign language instructors to adapt to foreign language teaching that uses technology, namely digital literacy in foreign language teaching (Solano et al., 2017; NUGRAHA et al., 2021; Sudarmo et al., 2021). Similarly, Cozma (2015), said that teaching English, especially speaking skills, is one of the most challenging teaching, not only teachers must find learning solutions but the activeness and breadth of teachers and students to explore methods that can accelerate their learning to communicate fluently in English quickly (Svensson et al., 2017). Moreover, to practice speaking skills, the teaching should be assisted by native speakers. Still, the problem in Indonesia is that teachers have to spend quite a lot of money, energy, and sincerity to get notifications. This cannot quickly happen if the educational institution or management does not have a strategy. And adequate financial capacity (Rajagopalan, 2015). Today's foreign language teaching specialists have researched several methods which are very relevant to be applied in teaching English as a foreign language, especially speaking or conversation skills (Jindathai, 2015; Suroso et al., 2021).

The findings of foreign language teaching experts firmly say that teaching English as a foreign language, especially communication or speaking skills, does not get trainers who are native speakers (Li et al., 2018; Ginaya et al., 2018). The alternative is that teachers or trainers can replace it with various digital technology applications available today in multiple countries. internet online sites (Erben et al., 2008). However, on the other hand, the trainer's ability and the teacher and their students must simultaneously learn English or speaking skills. They also have to master the skills in informatics or multimedia, so here we want to understand whether speaking skills indeed have a reasonable correlation quite significant on digital literacy skills (Shadiev et al., 2016). The reason why teaching English, especially speaking skills, is because speaking is one of the skills that express opinions and thoughts in a written speech where one has to tell his speech and thoughts verbally by following the rules of language or grammar and also with better pronunciation and structure. by accents that must match the context in which they are located (Gromik, 2012).

Therefore, proper English learning requires that teachers encourage students to express their thoughts and feelings in English often so that students are used to it (Hsu et al., 2013). As mentioned earlier that the most difficult challenge is how the teaching is following the existing difficulties, for example, because English is a foreign language (Poedjiastutie \& Oliver, 2017). So in Indonesia, very few instructors can be as close as possible to the teaching system carried out by native speakers, so the solution is to bring technology into the classroom, a solution to strengthen students in teaching technology skills (Nartiningrum \& Nugroho, 2020). Digital literacy is very difficult for Indonesian students because English is a foreign language for most foreign language students. Computers are also an unfamiliar skill, except for social groups with good technological backgrounds (Herrera Martínez, 2019). Likewise, those who have an environment that supports good English teaching have the skills to dare to speak as ideally learning foreign languages, especially English in speaking skills (Doiz et al., 2011).

\section{Materials and Methods}

Furthermore, this method section will present how we can finally carry out this study, from determining the problem, searching for data, presenting data, discussing it, and finally closing it (Hahn Fox \& Jennings, 2014). First, we reiterate that the purpose of this study is to understand whether there are similarities or relevant relationships between learning to speak English concerning mastering digital literacy skills (Prado \& Plourde, 2011). This study is a qualitative study that relies on secondary data by using a phenomenological approach. Here the author wants to obtain the broadest possible data utilizing electronic exploration to see the existing evidence. We visited several video books and databases related to the two variables being discussed (Hart, 2018).

After we find several data that we believe are relevant in answering this royal question, we first try to understand through data coding data evaluation and take in-depth interpretation steps so that each of these findings is closer to the question than possible. This study and do not forget to look at the validity and reliability of the data to be right on target (Dörnyei \& Csizér, 2012). We chose secondary data because we did this when Indonesia was in a period of coffee crisis where the government still imposed restrictions on public movement where the author was complicated to get to the field looking for the data needed. Exist in several publications that we mentioned above (Janssen et al., 2012). 
Based on the data we found and also discussed comprehensively, we finally concluded that this kingdom really had answered the question, so this study also follows the steps that have been carried out by previous studies on how to identify problems and also the system of writing methodologies and also Another study that is related to secondary data literature review (Habib et al., 2021). So once again, we repeat here that this work is to use second data from and descriptions of data analysis and is categorized as a qualitative study by exploring to gain understanding to answer the core questions of in the study of language and digital literacy (Durriyah \& Zuhdi, 2018).

\section{Results and Discussions}

\section{Technology and English practice}

The use of technology in English-speaking classes in this technological era is nothing new (Ersanli, 2016). Especially with the teaching conditions in Indonesia, which are still far from the required foreign language teaching standards to achieve success, especially teaching speaking skills (Mehrpour \& Vojdani, 2012). Considering again that digital literacy has become a common thing used in terms of research and business science and technology, digital technology has become something that can make work practically efficient and enable it to succeed as planned (Nawaz \& Kundi, 2010). For example, with the use of multimedia such as videos, digital worksheets, podcast applications, and also other websites, all of which are based on educational technology and their benefits have been proven in the context of learning English as a foreign language in countries that do not use English as the family language of education and the national language (Redondo, 2015).

It must be admitted that teaching English in Indonesia is not new, but success is still far from expectations. It can be seen that many outputs or university graduates have provided a curriculum from the beginning to have at least oral communication skills, but this fact is still far from expectations. The latest challenge is if today's technology has become a shared choice (Syatriana, 2013). However, if its use is still only limited to things that do not lead to education, this is something that must be addressed, and a solution is sought for why teaching technology has not been able to enter and become an innovative solution in teaching English as an international language (Henriksen et al., 2017).

The application of digital literacy in teaching speaking is believed to be the best way to create conversations in English, and this technology is the way that is recommended in the teaching curriculum in Indonesia (Kurniawati et al., 2018; Aslan et al., 2020; Rachmawati et al., 2020). According to Suherdi (2019), digital literacy is a highly scalable computer program for teaching that offers highly constructive improvements with method features not found in traditional teaching systems. So in this way, teachers can incorporate digital literacy into lesson plans (Alakrash et al., 2021), so that this teaching method will look more modern.

ITC expert, (Cakici, 2016), also said that today's technology is not a strange thing in teaching, especially English speaking, which is western about technology, how many people themselves create multimedia in various forms so that students anywhere in the world can access and use it into the system. their teaching (Zainal, 2012). Then as what Lichy et al. (2014), also said that with the concept of teaching foreign languages in non-English speaking countries, namely the imitation system of typing people's learning content, this could be done with the help of technology, namely teachers and schools can bring appropriate technology into payment classes so that there are children if they want to imitate how native speakers are more a way they can directly imitate what get through the digital technology they use in the classroom (Karakaş, 2013).

\section{Digital literacy and millennial students}

All educators are aware that digital literacy is not new in the Industry 4.0 era because, in that era, the millennial generation cannot be separated from technology. However, this digital application should facilitate millennial children's learning classes, including foreign languages, especially speaking teaching (Heriyanto et al., 2019). Regarding the relationship between technology and teaching English, (Coldwell-Neilson \& Cooper, 2019), said that since the digital technology revolution has penetrated the world of education throughout the world, Indonesia is one of the countries that has also adopted literacy technology in teaching through curriculum content that is mandated to be implemented in class (Churiyah et al., 2020).

Although at first many doubted how prepared the teachers and schools were to be able to apply technology into the classroom, but along with the changing times of millennial children, it was proven (Thomson, 2020), even though they

Muhammadiah, M., Pattiasina, P. J., Khasanah, K., \& Pirdaus, A. (2021). The relevance of speaking skills with improving digital literacy skills. International Research Journal of Management, IT and Social Sciences, 8(6), 669678. https://doi.org/10.21744/irjmis.v8n6.1975 
were separated by technological means, they still sought and wanted as much as possible (Manurung, 2015; Boonkit, 2010). Technology close to them. However, unfortunately, when technology cannot be empowered for the desired learning objectives, that is where the technology turns out to have not been able to provide benefits because governance and commitment and also given by the teachers have not been able to make this technology into an innovation that is ready to inspire students of the next generation of students-young people who live and learn in the millennial era (Seemiller \& Grace, 2017).

\section{Literacy digital and millennial speaking skill}

Kervin (2016), said that digital technology was unexpectedly effective in training children to communicate or, in other words, to communicate verbally or to speak because of digital technology (Light et al., 2019). This way is a means by which students can get information, and after that they use them, analyze them, describe them, analyze them, then they also convey it when they convey it orally in this conversation, it will be seen that anyone who has proficiency in digital technology will easily convey their thoughts and feelings in conversation (Wulandari, 2019). Students as learners who live socially, besides having to master various technological applications, on the other hand, must also be appropriate in social interactions both at school and outside of school (García \& Kleifgen, 2010).

So when they master both skills, when they succeed in mastering digital literacy. Many teachers believe that students will be successful in communicating because this communication is closely related to the information they have got, so today, the information that is most easily achieved is through digital literacy, where this technology can be accessed efficiently and very personally anytime and anywhere (Tschannen-Moran, 2014). When students are competent in that gap, they will have several skills and other information so that they can communicate their ideas, thoughts, and feelings verbally; in other words, they will be triumphant incompetence in speaking because all the cues that are in their minds can be transferred to them. This way is where teachers will see that students who are competent in technology are also competent in communication skills, namely speaking (Basic, 2011).

Plus, today's students who live in this technological era are already accustomed to information technology, so when the internet has become a part of their lives, they will quickly get news information (Brown \& Duguid, 2017). Students are also able to convey whatever they feel quickly because they are also in addition to the internet that trains or with what kind of information through this network they also get models of how to communicate as shared in videos that can be used on tik to which are posted on the internet. Share on social media and other platforms (Noel, 2021). This approach will inspire giving ease and courage to millennials, so they will indirectly be inspired by the models they see in the world of literacy (Kang, 2021).

Seeing the development of this literacy technology and the impact on communication, it is undeniable in this literacy technology if there are things that make losses, such as the challenge of making technology (Rajpal \& Devi, 2011). It becomes like food, so every food will also get some poison or something that does not bring any benefit, so here it takes skills and expertise from school management to as much as possible regulate and regulate the use of this technology in a positive direction (Vdovina et al., 2019). So that the efficiency and effectiveness of learning can be achieved, in other words, it is not easy to create a fast payment if it is still maintained in traditional ways by manual means by relying on human resources without the latest technology (Parveen, 2016), for that education management at Curriculum designers and learning material designers must understand the context and content of the benefits of digital technology (Mallayeva \& Ortiqova, 2020). This way is so that any teaching, including English, especially conversational and Viking skills, can benefit as much as possible and develop and progress of speaking skills (Yogman et al., 2018).

\section{Relevance technology and speaking skill mastery}

The four English speaking language skills are often considered a measure of a person's success in learning English (Bsharat \& Barahmeh, 2020). This approach is very reasonable, as stated (Idrus et al., 2011), that speaking skills have included other language skills, meaning that when speaking, people convey thoughts, ideas, and feelings, all ideas and feelings, of course, they have heard, read, even written, so that they are easy to understand when saying in daily conversation (Liyanage \& Bartlett, 2013). Because speaking skills are considered very influential on mastery of English, every foreign language learner tends to practice English with an emphasis on language productivity skills in addition to mastering pronunciation and intonation grammar (Saito \& Lyster, 2012).

According to Blyth (2018), speaking in English both in everyday reality and in the context of learning here, it is required for students to be able to interact with the environment, including with technological devices, which are the 
most innovative and productive learning resources today (Cakir \& Balcikanli, 2012). Therefore, teachers and trainers must also prepare themselves how to master digital technology in teaching and evaluation and improve the ability of the four language skills with an emphasis on speaking skills because these skills are used more dominantly in daily teaching (Smeda et al., 2014).

Suppose one of them, namely digital technology skills and English language skills, is absent (Aryani \& Rahayuni, 2016; Tavil, 2010). In that case, teachers will experience problems in presenting lessons, and they will experience failure, especially today's teaching consistently links the skills to master digital literacy with the skills to master conversation or speaking skills (Greenstein, 2012). Back to the old days when studying in the early 1990s when the most dominant foreign language learning media used recorders and radio but 30 years later when the technological revolution had penetrated In all sectors of life, both business and education, in the end, individuals who are not competent in these technological skills it will not be easy to develop a career both in the world of education and in the world of work they face (Watson \& Hill, 2015).

This way is one of the technological innovations that can innovate and revolutionize foreign language learning from conventional and traditional methods to fast learning methods using digital and everything fast, instant, and virtual (Chen, 2010). It is said that currently the world is being hit by the COVID-19 outbreak, all activities that have been carried out together at this time, the world community is forced to use technology to complete work programs and also education as an alternative solution by considering that technology is indeed compelling as a solution when outbreaks and peace crises disrupt education (Facer, 2011). Since the world was hit by the COVID-19 outbreak, the role of technology, mainly digital literacy, has been decisive, and governments worldwide have agreed to declare following the UNESCO order that when schools and universities must close, classes are opened. Online is consumed, distance learning occurs by juxtaposing technology to connect to replace face-to-face losers, it is indeed world policy not to continue learning such as face-to-face methods (Meskell, 2013).

\section{Conclusion}

In this construction section, the researcher wants to take some important points, which are the findings of this study which aims to gain a new understanding of how the relevance of speaking skills in learning English with digital literacy skills possessed by students both in college at school and English learners in general. Independent. In this way, the authors believe that the midwives we describe are sourced from studies of various data sources such as book communication journals and other relevant sources discussing issues related to the two variables above, namely speaking skills and students' digital literacy skills. It is undeniable that it can be seen with the naked eye that today school and college children are millennials who live and work and study and are inseparable from their connection with digital technology as well as when they learn foreign languages, it is not impossible they do not use digital to acquire materials and also how to practice speaking English by following the models and guides available on the internet.

Moreover, if we look at the evidence of the data that has been presented here, it is clear that there are eight which are pretty good; there is a significant difference between mastery of English speaking skills and proficiency in mastering digital technology. Whatever the content and purpose of the learning people want, there is almost no learning that does not use a learning tool called multimedia or digital literacy skills. Moreover, today the world and Indonesia, in particular, are still in a coastal atmosphere where learning is still partly carried out through Face to Face, and some who have already done it remotely will be seen that the application of this technology is not limited to specific lectures. However, all school and college subjects have a strong relevance meaning that one skill will not be achieved if the other skills are not included. So, at the end of this section of this paper, we would like to underline relevant friends and leaders to conclude this study. In this study, we mention that technology and practice are related, meaning that they are interrelated.

In another part, we also mentioned that digital literacy cannot be separated from the defense of English, where today students are millennials, so the characteristics of millennials are that all activities, both learning and beating their hobbies, are more likely to be close to digital applications that exist everywhere. Well, smartphones, computers, and laptops, so everything is very, very closely related to achievement and students and millennials. The following conclusion is how digitalization can improve the English language skills carried out by this young millennial generation. It has been stated here that a student, for example, has proficiency in digital, so it will be easy for him to reach their level of learning, not only in foreign languages but also in foreign languages.

Muhammadiah, M., Pattiasina, P. J., Khasanah, K., \& Pirdaus, A. (2021). The relevance of speaking skills with improving digital literacy skills. International Research Journal of Management, IT and Social Sciences, 8(6), 669 678. https://doi.org/10.21744/irjmis.v8n6.1975 
However, also for others, which today have all been integrated into applications or learning in virtual. Finally, we can say that the relevance of technology and mastery rather than speaking skills cannot be separated because one thing and another are interrelated. Moreover, this relevance can be seen in an everyday reality where students and technology cannot be separated, added to the findings in the database that there is quite a close relationship between mastery of foreign languages, especially speaking skills with mastery of literacy skills or digital technology that today it is known as multimedia or learning using technology. Thus, the study of these findings in the hope that this will be an essential input for efforts to develop learning English skills combined with technological literacy skills, which today have been able and proven to increase learning achievement and are also able to innovate and inspire many young people in efforts to accelerate learning, especially foreign languages as a mandatory language in Indonesia.

\section{Conflict of interest statement}

The authors declared that's they have no competing interests.

Statement of authorship

The authors have a responsibility for the conception and design of the study. The authors have approved the final article.

\section{Acknowledgments}

All authors are deeply grateful for the assistance in the form of academic and financial assistance, both from investments and from the government of the Republic of Indonesia through the Ministry of Education and Culture, especially the Directorate of Higher Education and Research. We realize that this study would not be possible; we could not carry it out as planned. Therefore, once again, we express our highest gratitude so that in the future, there will be more assistance and attention for the implementation of projects in the effort to develop science and knowledge in universities. 


\section{References}

Alakrash, H., Razak, N. A., \& Krish, P. (2021). Social Network Sites in Learning English; An Investigation on Attitudes, Digital Literacy and Usage. LINGUISTICA ANTVERPIENSIA, 26-43.

Aryani, I. G. A. I., \& Rahayuni, N. K. S. (2016). Innovation of teaching and learning english applied to animal sciences' student with the combination of computer media and audio visual. International Journal of Linguistics, Literature and Culture, 2(1), 1-7. Retrieved from https://sloap.org/journals/index.php/ijllc/article/view/78

Aslan, A., Silvia, S., Nugroho, B. S., Ramli, M., \& Rusiadi, R. (2020). Teacher's leadership teaching strategy supporting student learning during the covid-19 disruption. Nidhomul Haq: Jurnal Manajemen Pendidikan Islam, 5(3), 321-333.

Basic, L. (2011). Speaking anxiety: an obstacle to second language learning?.

Blyth, C. (2018). Immersive technologies and language learning. Foreign Language Annals, 51(1), $225-232$.

Boonkit, K. (2010). Enhancing the development of speaking skills for non-native speakers of English. Procedia-social and behavioral sciences, 2(2), 1305-1309. https://doi.org/10.1016/j.sbspro.2010.03.191

Brown, J. S., \& Duguid, P. (2017). The social life of information: Updated, with a new preface. Harvard Business Review Press.

Bsharat, T. R., \& Barahmeh, M. Y. (2020). The Influence of Applying Educational Active Drama in Enhancing Speaking Skills in Teaching-Learning English Language: A Theoretical Response. Technium Soc. Sci. J., 14, 10.

Cakici, D. (2016). The use of ICT in teaching English as a foreign language. Participatory Educational Research, 4(2), 73-77.

Cakir, A., \& Balcikanli, C. (2012). The use of the EPOSTL to foster teacher autonomy: ELT student teachers' and teacher trainers' views. Australian Journal of Teacher Education (Online), 37(3), 1-16.

Chen, M. (2010). Education nation: Six leading edges of innovation in our schools. John Wiley \& Sons.

Churiyah, M., Sholikhan, S., Filianti, F., \& Sakdiyyah, D. A. (2020). Indonesia education readiness conducting distance learning in Covid-19 pandemic situation. International Journal of Multicultural and Multireligious Understanding, 7(6), 491-507.

Coldwell-Neilson, J., \& Cooper, T. (2019). Digital literacy meets industry 4.0. In Education for Employability (Volume 2) (pp. 37-50). Brill Sense.

Cozma, M. (2015). The Challenge of Teaching English to Adult Learners in Today's World. Procedia-social and behavioral sciences, 197, 1209-1214. https://doi.org/10.1016/j.sbspro.2015.07.380

Doiz, A., Lasagabaster, D., \& Sierra, J. M. (2011). Internationalisation, multilingualism and English-medium instruction. World Englishes, 30(3), 345-359.

Dörnyei, Z., \& Csizér, K. (2012). How to design and analyze surveys in second language acquisition research. Research methods in second language acquisition: A practical guide, 1, 74-94.

Durriyah, T. L., \& Zuhdi, M. (2018). Digital literacy with EFL student teachers: Exploring Indonesian student teachers' initial perception about integrating digital technologies into a teaching unit. International Journal of Education and Literacy Studies, 6(3), 53-60.

Erben, T., Ban, R., \& Castaneda, M. (2008). Teaching English language learners through technology. Routledge.

Ersanli, C. Y. (2016). Improving Technological Pedagogical Content Knowledge (TPACK) of Pre-Service English Language Teachers. International Education Studies, 9(5), 18-27.

Facer, K. (2011). Learning futures: Education, technology and social change. Taylor \& Francis.

García, O., \& Kleifgen, J. A. (2010). Educating emergent bilinguals: Policies, programs, and practices for English language learners. Teachers College Press.

Ginaya, G., Rejeki, I. N. M., \& Astuti, N. N. S. (2018). The effects of blended learning to students' speaking ability: A study of utilizing technology to strengthen the conventional instruction. International Journal of Linguistics, Literature and Culture, 4(3), 1-14. Retrieved from https://sloap.org/journals/index.php/ijllc/article/view/158

Greenstein, L. M. (2012). Assessing 21 st century skills: A guide to evaluating mastery and authentic learning. Corwin Press.

Gromik, N. A. (2012). Cell phone video recording feature as a language learning tool: A case study. Computers \& education, 58(1), 223-230. https://doi.org/10.1016/j.compedu.2011.06.013

Habib, M. S., Ahmed, S., MunirLaghari, A., \& MubashirSaleem, M. (2021). Challenges of Defining and Revitalizing/Reawakening of Islamic Civilization in Contemporary Era. Ilkogretim Online, 20(4).

Hahn Fox, B., \& Jennings, W. G. (2014). How to write a methodology and results section for empirical research. Journal of Criminal Justice Education, 25(2), 137-156.

Muhammadiah, M., Pattiasina, P. J., Khasanah, K., \& Pirdaus, A. (2021). The relevance of speaking skills with improving digital literacy skills. International Research Journal of Management, IT and Social Sciences, 8(6), 669678. https://doi.org/10.21744/irjmis.v8n6.1975 
Hart, C. (2018). Doing a literature review: Releasing the research imagination.

Henriksen, D., Richardson, C., \& Mehta, R. (2017). Design thinking: A creative approach to educational problems of practice. Thinking skills and Creativity, 26, 140-153. https://doi.org/10.1016/j.tsc.2017.10.001

Heriyanto, H., Komariah, A., Satori, D., \& Suryana, A. (2019). Character education in the era of industrial revolution 4.0 and its relevance to the high school learning transformation process. Utopía y praxis latinoamericana: revista internacional de filosofía iberoamericana y teoría social, (5), 327-340.

Herrera Martínez, T. C. (2019). Challenges English for Specific Purposes (ESP) teachers face in a vocational institution: a case study (Master's thesis, Universidad del Norte).

Hsu, C. K., Hwang, G. J., \& Chang, C. K. (2013). A personalized recommendation-based mobile learning approach to improving the reading performance of EFL students. Computers \& Education, 63, 327-336. https://doi.org/10.1016/j.compedu.2012.12.004

Idrus, H., Salleh, R., \& Lim Abdullah, M. R. T. (2011). Oral Communication Ability In English: An Essential Skill For Engineering Graduates. Journal of Educators \& Education/Jurnal Pendidik dan Pendidikan, 26.

Janssen, M., Charalabidis, Y., \& Zuiderwijk, A. (2012). Benefits, adoption barriers and myths of open data and open government. Information systems management, 29(4), 258-268.

Jindathai, S. (2015). Factors affecting English speaking problems among engineering students at Thai-Nichi Institute of Technology. TNI Journal of Business Administration and Languages, 3(2), 26-30.

Kang, J. (2021). Designing an Online Platform to Support Long-Distance Romantic Relationships (Doctoral dissertation, Syracuse University).

Karakaş, A. (2013). Is communicative language teaching a panacea in ELT?-Student and teacher perspectives. Journal of Second and Multiple Language Acquisition, 1(1), 1-19.

Kervin, L. (2016). Powerful and playful literacy learning with digital technologies. Australian Journal of Language and Literacy, 39(1), 64-73.

Kurniawati, N., Maolida, E. H., \& Anjaniputra, A. G. (2018). The praxis of digital literacy in the EFL classroom: Digital-immigrant vs digital-native teacher. Indonesian Journal of Applied Linguistics, 8(1), 28-37.

Li, H., Booth, J. R., Bélanger, N. N., Feng, X., Tian, M., Xie, W., ... \& Ding, G. (2018). Structural correlates of literacy difficulties in the second language: Evidence from Mandarin-speaking children learning English. NeuroImage, 179, 288-297. https://doi.org/10.1016/j.neuroimage.2018.06.037

Lichy, J., Khvatova, T., \& Pon, K. (2014). Engaging in digital technology: one size fits all?. Journal of Management Development.

Light, J., McNaughton, D., Beukelman, D., Fager, S. K., Fried-Oken, M., Jakobs, T., \& Jakobs, E. (2019). Challenges and opportunities in augmentative and alternative communication: Research and technology development to enhance communication and participation for individuals with complex communication needs. Augmentative and Alternative Communication, 35(1), 1-12.

Liyanage, I., \& Bartlett, B. (2013). Personality types and languages learning strategies: Chameleons changing colours. System, 41(3), 598-608. https://doi.org/10.1016/j.system.2013.07.011

Mallayeva, O., \& Ortiqova, E. (2020). The Technology of teaching foreign monologue speaking. Архив Научных Публикаиий JSPI.

Manurung, K. (2015). Improving the speaking skill using reading contextual internet-based instructional materials in an EFL class in Indonesia. Procedia-Social and Behavioral Sciences, 176, 44-51. https://doi.org/10.1016/j.sbspro.2015.01.442

Mehrpour, S., \& Vojdani, M. (2012). Globalization and EFL learning motivation: A new perspective on integrative vs. instrumental motivation among Iranian learners of English. Open Journal of Modern Linguistics, 2(02), 43.

Meskell, L. (2013). UNESCO's World Heritage Convention at 40: Challenging the economic and political order of international heritage conservation. Current anthropology, 54(4), 483-494.

Nartiningrum, N., \& Nugroho, A. (2020). Online learning amidst global pandemic: EFL students' challenges, suggestions, and needed materials. ENGLISH FRANCA: Academic Journal of English Language and Education, 4(2), 115-140.

Nawaz, A., \& Kundi, G. M. (2010). Digital literacy: An analysis of the contemporary paradigms. International Journal of Science and Technology Education Research, 1(2), 19-29.

Noel, J. E. (2021). College Students' Experiences with Social Media Information Sharing and Sexting, Bullying, and Cyberstalking: A Qualitative Phenomenological Study (Doctoral dissertation, Northcentral University).

Nomass, B. B. (2013). The impact of using technology in teaching English as a second language. English language and literature studies, 3(1), 111. 
NUGRAHA, M. S., LIOW, R., \& EVLY, F. (2021). The Identification of Online Strategy Learning Results While Students Learn from Home During the Disruption of the COVID-19 Pandemic in Indonesia. Journal of Contemporary Issues in Business and Government, 27(2), 1950-1956.

Parveen, B. W. (2016). Use of technology in improving speaking skills. Journal of English language and literature (JOELL), 3(2).

Poedjiastutie, D., \& Oliver, R. (2017). English learning needs of ESP learners: Exploring stakeholder perceptions at an Indonesian University. Teflin Journal, 28(1), 1-21.

Prado, L., \& Plourde, L. A. (2011). Increasing reading comprehension through the explicit teaching of reading strategies: Is there a difference among the genders?. Reading improvement, 48(1), 32-44.

Putra, P., Liriwati, F. Y., Tahrim, T., Syafrudin, S., \& Aslan, A. (2020). The students learning from home experience during covid-19 school closures policy in indonesia. Jurnal Iqra, 5(2).

Putra, P., Mizani, H., Basir, A., Muflihin, A., \& Aslan, A. (2020). The Relevancy on Education Release Revolution 4.0 in Islamic Basic Education Perspective in Indonesia (An Analysis Study of Paulo Freire's Thought). Test Engineering \& Management, 83, 10256-10263.

Rachmawati, M., Widjajanti, S., Ahmad, A., \& Aslan, A. (2020). The English Camps as Method of Promoting Fun English at Elementary School Level in Indonesia. Tapis: Jurnal Penelitian Ilmiah, 4(2), 174-182.

Rajagopalan, K. (2015). On the challenge of teaching English in Latin America with special emphasis on Brazil. In Resistance to the Known (pp. 121-143). Palgrave Macmillan, London.

Rajpal, S., \& Devi, V. A. (2011). Podcast: Enhancing Listening and Speaking Skills. Language in India, 11(10).

Redondo, T. (2015). The digital economy: Social interaction technologies-an overview.

Saito, K., \& Lyster, R. (2012). Effects of form-focused instruction and corrective feedback on L2 pronunciation development of/s/by Japanese learners of English. Language learning, 62(2), 595-633.

Seemiller, C., \& Grace, M. (2017). Generation Z: Educating and engaging the next generation of students. About Campus, 22(3), 21-26.

Shadiev, R., Hwang, W. Y., Huang, Y. M., \& Liu, C. J. (2016). Investigating applications of speech-to-text recognition technology for a face-to-face seminar to assist learning of non-native English-speaking participants. Technology, Pedagogy and Education, 25(1), 119-134.

Smeda, N., Dakich, E., \& Sharda, N. (2014). The effectiveness of digital storytelling in the classrooms: a comprehensive study. Smart Learning Environments, 1(1), 1-21.

Solano, L., Cabrera, P., Ulehlova, E., \& Espinoza, V. (2017). Exploring the Use of Educational Technology in EFL Teaching: A Case Study of Primary Education in the South Region of Ecuador. Teaching English with technology, 17(2), 77-86.

Sudarmo, S., Arifin, A., Pattiasina, P. J., Wirawan, V., \& Aslan, A. (2021). The Future of Instruction Media in Indonesian Education: Systematic Review. AL-ISHLAH: Jurnal Pendidikan, 13(2), 1302-1311.

Suherdi, D. (2019). Teaching English in the industry 4.0 and disruption era: Early lessons from the implementation of SMELT I 4.0 DE in a senior high lab school class. Indonesian Journal of Applied Linguistics, 9(1), 67-75.

Suroso, A., Hendriarto, P., Mr, G. N. K., Pattiasina, P. J., \& Aslan, A. (2021). Challenges and opportunities towards Islamic cultured generation: socio-cultural analysis. Linguistics and Culture Review, 5(1), 180-194.

Svensson, V., Natarajan, K. N., Ly, L. H., Miragaia, R. J., Labalette, C., Macaulay, I. C., ... \& Teichmann, S. A. (2017). Power analysis of single-cell RNA-sequencing experiments. Nature methods, 14(4), 381-387.

Syatriana, E. (2013). A Model of Creating Instructional Materials Based on the School Curriculum for Indonesian Secondary Schools.

Tavil, Z. M. (2010). Integrating listening and speaking skills to facilitate English language learners' communicative competence. Procedia-Social and Behavioral Sciences, 9, 765-770. https://doi.org/10.1016/j.sbspro.2010.12.231

Thomson, P. (2020). Schooling the rustbelt kids: Making the difference in changing times. Routledge.

Tschannen-Moran, M. (2014). Trust matters: Leadership for successful schools. John Wiley \& Sons.

Vdovina, E. K., Popova, N. V., Gavrilova, A. V., \& Kuzmina, A. V. (2019). Video technology for teaching foreign language speaking skills in a technical university. In 12th International Conference of Education, Research and Innovation ICERI 2019 Proceedings (pp. 9747-9757).

Watson, J., \& Hill, A. (2015). Dictionary of media and communication studies. Bloomsbury Publishing USA.

Wulandari, M. (2019). Improving EFL learners' speaking proficiency through instagram vlog. LLT Journal: A Journal on Language and Language Teaching, 22(1), 111-125.

Muhammadiah, M., Pattiasina, P. J., Khasanah, K., \& Pirdaus, A. (2021). The relevance of speaking skills with improving digital literacy skills. International Research Journal of Management, IT and Social Sciences, 8(6), 669678. https://doi.org/10.21744/irjmis.v8n6.1975 
Yogman, M., Garner, A., Hutchinson, J., Hirsh-Pasek, K., \& Golinkoff, R. M. (2018). Aap committee on psychosocial aspects of child and family health, Aap council on communications and media. The power of play: A pediatric role in enhancing development in young children. Pediatrics, 142(3), e20182058.

Zainal, A. (2012). ESL teachers' use of ICT in teaching English literature: An analysis of teachers' TPCK. ProcediaSocial and Behavioral Sciences, 34, 234-237. https://doi.org/10.1016/j.sbspro.2012.02.047 